\title{
TINGKAT KETERBACAAN KOMPETENSI DASAR BAHASA INDONESIA PADA KURIKULUM 2013 DAN KORELASINYA DENGAN KEMAMPUAN MENGAJAR BAGI GURU
}

\author{
Ratnawati Dewi ${ }^{1}$ \\ Abdul. Rahman Rahim²* \\ Andi Sukri Syamsuri ${ }^{3}$ \\ ${ }^{1}$ SDN I Pakalu I Kabupaten Maros, Indonesia \\ ${ }^{2,3}$ Universitas Muhammadiyah Makassar, Makassar Indonesia \\ ratnawatidewi38@gmail.com ${ }^{1)}$ \\ rahman@unismuh.ac.id ${ }^{2 *}$ \\ andhies@unismuh.ac.id ${ }^{3)}$
}

\begin{abstract}
Abstrak
Kompetensi dasar bahasa Indonesia dalam Kurikulum 2013 diubah dari Kurikulum 2006 dari pendekatan komunikatif ke pendekatan teks. Hal ini menjadi persoalan karena banyak unsur yang harus dimasukkan dalam komptensi tersebut. Banyak kompetensi dasar yang oleh banyak guru tidak jelas maksudnya, strategi pembelajarannya, serta tuidak jelas penerapannya. Untuk mengungkap secara jelas persoalan tersebut, dilakukan penelitian mengenai tingkat keterbacaan dengan kaitannya dengan kemampuan mengajar guru. Oleh karena itu, tujuan utama penelitian ini yaitu untuk melihat ada tidaknya korelasi antara tingkat keterbacaan kompetensi dasar bahasa Indonesia pada Kurikulum 2013 dan Kemampuan mengajar guru SDN I Pakalu I Kabupaten Maros. Penelitian ini dilaksanaan di SDN I Pakalu I Kabupaten Maros menggunakan metode kuantitaif dengan teknik pengetesan terhadap keterbacaan KD Bahasa Indonesia K.13 guru dan pengamatan kemampuan mengajar bahasa Indonesia sebanya 12 orang guru. Data dianalaisis menggunakan Uji-R Person Product Moment dengan taraf signifikansi 95\% (0,5). Hasil penelitian menunjukkan bahwa terdapat korelasi antara tingkat keterbacaan kompetensi dasar bahasa Indonesia pada Kurikulum 2013 dan Kemampuan mengajar guru guru SDN I Pakalu I Kabupaten Maros. Hal ini dtunjukkan pada hasil uji hipotesis yakni nilai R hitung lebih besar daripada nilai $\mathrm{R}$ tabel pada taraf signifikansi $95 \%(0,5)$ yakni: $0,5999>0,45,75$ dengan tingkat korelasi sangat kuat.
\end{abstract}

Kata Kunci: Keterbacaan, Kompetensi Dasar Bahasa Indonesia, dan Kemampuan Mengajar

Published by:

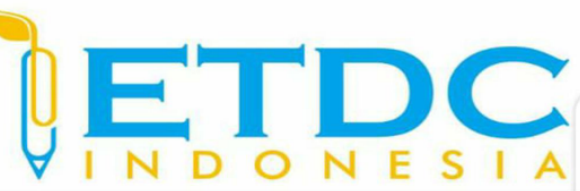

Copyright (C) 2021 The Author (s)

This article is licensed under CC BY 4.0 License

(cc) $\mathrm{BY}$ 


\section{TINGKAT KETERBACAAN KOMPETENSI DASAR BAHASA INDONESIA PADA KURIKULUM 2013 DAN KORELASINYA DENGAN KEMAMPUAN MENGAJAR BAGI GURU}

\section{Pendahuluan}

Kurikulum sebagaimana yang ditegaskan dalam Pasal 1 Ayat (19) Undang-Undang Nomor 20 Tahun 2003 adalah seperangkat rencana dan pengaturan mengenai tujuan, isi, dan bahan pelajaran serta cara yang digunakan sebagai pedoman penyelenggaraan kegiatan pembelajaran untuk mencapai tujuan pendidikan tertentu. Pengembangan Kurikulum 2013 merupakan langkah lanjutan Pengembangan Kurikulum Berbasis Kompetensi yang telah dirintis pada tahun 2004 dan KTSP 2006 yang mencakup kompetensi sikap, pengetahuan, dan keterampilan secara terpadu. Pengembangan kurikulum perlu dilakukan karena adanya berbagai tantangan yang dihadapi, baik tantangan internal maupun tantangan eksternal. Tantangan internal antara lain terkait dengan kondisi pendidikan dikaitkan dengan tuntutan pendidikan yang mengacu kepada 8 (delapan) Standar Nasional Pendidikan yang meliputi standar pengelolaan, standar biaya, standar sarana prasarana, standar pendidik dan tenaga kependidikan, standar isi, standar proses, standar penilaian, dan standar kompetensi lulusan.

Tantangan internal lainnya terkait dengan faktor perkembangan penduduk Indonesia dilihat dari pertumbuhan penduduk usia produktif. Terkait dengan tantangan internal pertama, berbagai kegiatan dilaksanakan untuk mengupayakan agar penyelenggaraan pendidikan dapat mencapai ke delapan standar yang telah ditetapkan. Pendidikan yang sesuai dengan kebutuhan masa depan hanya akan dapat terwujud apabila terjadi pergeseran atau perubahan pola pikir. Pergeseran itu meliputi proses pembelajaran sebagai berikut, dari berpusat pada guru menuju berpusat pada siswa,dari satu arah menuju interaktif. Dari isolasi menuju lingkungan jejaring, dari pasif menuju aktif-menyelidiki, dari maya/abstrak menuju konteks dunia nyata,dari pembelajaran pribadi menuju pembelajaran berbasis tim, dari luas menuju perilaku khas memberdayakan kaidah keterikatan, dari stimulasi rasa tunggal menuju stimulasi ke segala penjuru, dari alat tunggal menuju alat multimedia, dari hubungan satu arah bergeser menuju kooperatif, dari produksi massa menuju kebutuhan pelanggan, dari usaha sadar tunggal menuju jamak, dari satu ilmu pengetahuan bergeser menuju pengetahuan disiplin jamak, dari kontrol terpusat menuju otonomi dan kepercayaan, dari pemikiran faktual menuju kritis, dari penyampaian pengetahuan menuju pertukaran pengetahuan.

Dengan demikian Kurikulum 2013 adalah dirancang dengan tujuan untuk mempersiapkan insan Indonesia supaya memiliki kemampuan hidup sebagai pribadi dan 
warganegara yang beriman, produktif, kreatif, inovatif, dan afektif serta mampu berkontribusi pada kehidupan bermasyarakat, berbangsa, bernegara dan peradaban dunia. Kurikulum adalah instrumen pendidikan untuk dapat membawa insan Indonesia memiliki kompetensi sikap, pengetahuan, dan keterampilan sehingga dapat menjadi pribadi dan warga negara yang produktif, kreatif, inovatif, dan afektif.

Secara singkat kurikulum adalah untuk membangun kehidupan masa kini dan masa akan datang bangsa, yang dikembangkan dari warisan nilai dan pretasi bangsa di masa lalu, serta kemudian diwariskan serta dikembangkan untuk kehidupan masa depan. Ketiga dimensi kehidupan bangsa, masa lalu-masa sekarang-masa yang akan datang, menjadi landasan filosofis pengembangan kurikulum. Masalahnya sekarang penerapan Kurikulum 2013 masih menghadapi banyak permasalahan, baik teknis maupun konten materi kurikulum bagi guru. Salah satu mata pelajaran yang dianggap masih menuai masalah adalah bahasa Indonesia sekolah dasar. Kompetensi dasar bahasa Indonesia dalam Kurikulum 2013 diubah dari Kurikulum 2006 dari pendekatan komunikatif ke pendekatan teks. Hal ini menjadi persoalan karena banyak unsur yang harus dimasukkan dalam komptensi tersebut. Banyak kompetensi dasar yang oleh banyak guru tidak jelas maksudnya, strategi pembelajarannya, serta tuidak jelas penerapannya. Hasil wawancara kepada beberapa guru SD di kabupaten Maros, menunjukkan bahwa kompetensi dasar bahasa Indonesia Kurikulum 2013 banyak yang sulit dipahami, bahkan secara subtansi tidak jelas oleh guru.

Untuk memperoleh gambaran yang jelas mengenai persoalan tersebut, penulis terdorong melakukan penelitian tingkat keterbacan guru terhadap kompetensi dasar bahasa Indonesia Kurikulum 2013 dan kaitannya dengan kemampuan mengajar guru. Adapun tujuan yang diungkap dalam penelitian ini adalah mewmbuktikan ada tidaknya korelasi antara tingkat keterbacaan kompetensi dasar bahasa Indonesia pada Kurikulum 2013 dan Kemampuan mengajar guru SDN I Pakalu I Kabupaten Maros. Penelitian ini relevan dengan hasil penelitian Aman (2016) yang menunjukkan bahwa guru-guru SD Negeri 37 Majang Kabupaten Bone, memiliki tingkat keterbacaan kompetensi dasar Bahasa Indonesia Kurikulum 2013 belum memadai. Hal ini terlihat dari tiga hal yaitu, pemahaman tentang maksud komptensi dasar, teknik pembelajaran kompetensi dasar, dan konsep penilaian terkait komptensi dasar. Penelitian senada diungkapkan oleh Basyir (2017) bahwa guru-guru SD di Gugus II Kecamamatan Polewali masih memiliki pemahaman yang rendah terhadap materi esensial pada kompetensi dasar bahasa Indonesia kurikulum 2013. 


\section{Tinjauan Literatur}

Hakikat kurikulumoleh Suparlan (2013) kurikulum adalah pengalaman pembelajaran yang terarah dan juga terencana dengan secara terstuktur dan juga tersusun dengan melalui proses rekontruksi pengetahuan serta pengalaman secara sistematis yang berada dibawah suatu pengawasan lembaga pendidikan sehingga pelajar tersebut mempunyai motivasi dan juga minat belajar. Menurut Rachmad (2011) kurikulum ialah usaha menyeluruh yang dirancang secara khusus oleh sekolah di dalam membimbing murid untuk dapat memperoleh hasil dari pelajaran yang telah ditentukan tersebut. Menurut Taba (Syukron, 2012) bahwa kurikulum ialah sebuah pembelajaran yang dirancang dan juga dilaksanakan dengan individu serta juga berkelompok baik itu di luar ataupun di dalam sekolah. Menurut George A. Beaucham (Ginting, 2011), Pengertian kurikulum ialah suatu dokumen tertulis yang didalamnya terkandung isi mata pelajaran yang akan diajar kepada peserta didik (murid) dengan melalui berbagai mata pelajaran, pilihan disiplin ilmu, rumusan masalah yang dalam kehidupan sehari-hari. Menurut Neagley dan Evans (Jayora, 2013) menyatakan kurikulum ialah semua pengalaman yang telah dibangung atau dirancang oleh pihak sekolah untuk dapat menolong para siswa didalam mencapai hasil belajar kepada kemampuan siswa yang paling baik.

Secara yuridis Kurikulum diartikan sebagai seperangkat rencana dan pengaturan mengenai tujuan, isi dan bahan pelajaran serta cara yang digunakan sebagai pedoman penyelenggaraan kegiatan pembelajaran untuk mencapai tujuan pendidikan tertentu. Tujuan tertentu ini meliputi tujuan pendidikan nasional serta kesesuaian dengan kekhasan, kondisi dan potensi daerah, satuan pendidikan dan peserta didik (Kemendiknas, 2013). Oleh sebab itu kurikulum disusun oleh satuan pendidikan untuk memungkinkan penyesuaian program pendidikan dengan kebutuhan dan potensi yang ada di daerah.

Menurut Hasan (2000) bahwa kurikulum merupakan sejumlah pengalaman pendidikan, kebudayaan,sosial, olahraga, dan kesenian yang disediakan sekolah untuk anak didiknnya baik di dalam maupun di luar sekolah dengan maksud menolongnya agar dapat berkembang secara menyeluruh di semua aspeknya dan mengubah tingkah laku mereka sesuai dengan tujuantujuan pendidikan. Dengan demikian perubahan kurikulum, termasuk Kurikulum 2013 adalah dirancang dengan tujuan untuk mempersiapkan insan Indonesia supaya memiliki kemampuan hidup sebagai pribadi dan warganegara yang beriman, produktif, kreatif, inovatif, dan afektif serta mampu berkontribusi pada kehidupan bermasyarakat, berbangsa, bernegara dan peradaban dunia. Kurikulum adalah instrumen pendidikan untuk dapat membawa insan Indonesia memiliki kompetensi sikap, pengetahuan, dan keterampilan sehingga dapat menjadi pribadi dan warga negara yang produktif, kreatif, inovatif, dan afektif. 
Kurikulum 2013 dikembangkan berdasarkan ketentuan yuridis yang mewajibkan adanya pengembangan kurikulum baru, landasan filosofis, dan landasan empirik. Landasan yuridis merupakan ketentuan hukum yang dijadikan dasar untuk pengembangan kurikulum dan yang mengharuskan adanya pengembangan kurikulum baru. Landasan filosofis adalah landasan yang mengarahkan kurikulum kepada manusia apa yang akan dihasilkan kurikulum. Landasan teoritik memberikan dasar-dasar teoritik pengembangan kurikulum sebagai dokumen dan proses. Landasan empirik memberikan arahan berdasarkan pelaksanaan kurikulum yang sedang berlaku di lapangan.

Penilaian autentik memiliki relevansi kuat terhadap pendekatan ilmiah dalam pembelajaran sesuai dengan tuntutan Kurikulum 2013. Linda (2014) mengemukakan bahwa “Kurikulum 2013 mempertegas adanya pergeseran dalam melakukan penilaian, yakni dari penilaian melalui tes (berdasarkan hasil saja), menuju penilaian autentik (mengukur sikap, keterampilan, dan pengetahuan berdasarkan proses dan hasil)". Penilaian ini mampu menggambarkan peningkatan hasil belajar peserta didik, baik dalam rangka mengobservasi, menalar, mencoba, dan membangun jejaring. Penilaian autentik dilakukan oleh guru dalam bentuk penilaian kelas melalui penilaian kinerja, portofolio, produk, projek, tertulis, dan penilaian diri.

Kunandar (2013) mengemukakan bahwa "Kurikulum 2013 mempertegas adanya pergeseran dalam melakukan penilaian, yakni dari penilaian melalui tes (berdasarkan hasil saja), menuju penilaian autentik (mengukur sikap, keterampilan, dan pengetahuan berdasarkan proses dan hasil)". Penilaian ini mampu menggambarkan peningkatan hasil belajar peserta didik, baik dalam rangka mengobservasi, menalar, mencoba, dan membangun jejaring. Penilaian autentik dilakukan oleh guru dalam bentuk penilaian kelas melalui penilaian kinerja, portofolio, produk, projek, tertulis, dan penilaian diri. Asesmen seharusnya didasarkan pada pengetahuan kita tentang belajar dan tentang bagaimana kompetensi berkembang dalam materi pelajaran yang kita ajarkan. Hal ini merupakan kebutuhan yang sangat jelas untuk membuat suatu asesmen dimana pendidik dapat mempergunakannya untuk meningkatkan kegiatan pendidikan dan mengawasi hasil belajar dan mengajar yang kompleks.

\section{Metode Penelitian}

Penelitian ini merupakan penelitian deskriptif-korelasional yang berupaya mengungkap data apa adanya melalui deskriptif dan menghubungkannya dengan variablel lainnya. Metode deskripstif ini pada prinsipnya adalah mengkaji variabel sejajar yaitu tingkat keterbacaan kompetensi dasar bahasa Indonesia pada Kurikulum 2013 dan korelasinya dengan kemampuan 
mengajar bagi guru SDN I Pakalu I Kabupaten Maros.

Populasi atau subjek dalam penelitian ini adalah seluruh guru SDN I Pakalu I Kabupaten Maros tahun pelajaran 2020/2021. Populasi tersebut berjumlah 12 orang yang terbagi dalam 12 kelas, yaitu kelas 1A 1B, 2A, 2B, 3A, 3B, 4A, 4B, 5A, 5B, 6A, dan 6B. Karena jumlah populasi penelitian dan sesuai dengan karakterisktik penelitian, maka seluruh populasi dijadikan subjek penelitian (Total Sampling). Jadi seluruh populasi menjadi objek penelitian (12 orang).

Data dalam penelitian ini dikumpulkan melalui dua teknik yaitu (1) Teknik tes (pengetesan pemahaman) bagi guru terhadap KD bahasa Indonesia sesuaI tingkatan kelas. Instrumen yang digunakan adalah tes esai berkaitan dengan tiga hal yaitu makna KD, teknik pembelajaran, dan cara menilai. (2) Observasi. Observasi digunakan untuk memperoleh data menenai kemampuan mengajar guru. Instrmen yang digunakan adalah lembar observasi proses pembelajaran yang umum digunakan dalam PBM kurikulum 2013. Data dalam penelitian ini dianalisis menggunakan statistik inferensial dengan analisis Uji Pearson Product Moment (UjiR) yang salah satu dari beberapa jenis uji korelasi yang digunakan untuk mengetahui derajat keeratan hubungan dua variabel yang berskala interval atau rasio.

3. Hasil dan Pembahasan

a. Hasil Penelitian

1) Tingkat keterbacaan KD bahasa Indonesia K.13 guru SDN 1 Pakalu 1 Kabupaten Maros

Berdasarkan skor mentah, tingkat Keterbacaan KD bahasa Indonesia Kurikulum 2013 guru SDN I Pakalu I Kecamatan Bantimurung, Kabupaten Maros dapat dilihat pada tabel berikut:

Tabel 1. Statistik skor keterbacaan KD Bahasa Indonesia guru

\begin{tabular}{cc}
\hline Statistik & Nilai Statistik \\
\hline Subjek & 12 \\
Skor Ideal & 100 \\
Skor Tertinggi & 88,33 \\
Skor Terendah & 50,00 \\
Skor Rata-rata & 69,44 \\
\hline
\end{tabular}

Tabel 1 menunjukkan bahwa skor rata-rata tingkat keterabacaan KD Bahasa Indonesia guru SDN I Pakalu 1 Kabupaten Maros dengan subjek/responden penelitian 12 orang guru sebesar 69,44. Skor yang dicapai responden tersebar dengan skor tertinggi 88,33 dan skor terendah 50 dari skor tertinggi yang mungkin dicapai 100 dan skor terendah yang mungkin dicapai 0 . Hal ini menunjukkan bahwa rata-rata tingkat keterabacaan 
KD Bahasa Indonesia guru SDN I Pakalu 1 Kabupaten Maros berada pada kategori sedang.

2) Tingkat kemampuan mengajar guru SDN I Pakalu 1 Kabupaten Maros

Tingkat kemampuan mengajar bahasa Indonesia guru SDN I Pakalu I Kecamatan

Bantimurung, Kabupaten Maros dapat dilihat pada tabel 2 berikut:

Tabel 2. Statistik skor tingkat kemampuan mengajar guru SDN I Pakalu 1 Kabupaten Maros

\begin{tabular}{cc}
\hline Statistik & Nilai Statistik \\
\hline Subjek & 12 \\
Skor Ideal & 100 \\
Skor Tertinggi & 85,63 \\
Skor Terendah & 66,88 \\
Skor Rata-rata & 74,17 \\
\hline
\end{tabular}

Tabel 2 menunjukkan bahwa skor rata-rata tingkat kemampuan mengajar bahasa Indonesia guru SDN I Pakalu I Kecamatan Bantimurung, Kabupaten Maros dengan sebanyak 12 guru sebesar 74,17. Skor yang dicapai responden tersebar dengan skor tertinggi 85,63 dan skor terendah 68,75 dari skor tertinggi yang mungkin dicapai 100 dan skor terendah yang mungkin dicapai 0 . Hal ini menunjukkan bahwa rata-rata tingkat kemampuan mengajar bahasa Indonesia guru SDN I Pakalu I Kecamatan Bantimurung, Kabupaten Maros berada pada kategori sedang.

\section{3) Pengujian Hipotesis ( uji korelasi)}

Berdasarkan hasil analisis data di atas, dapat dipahami bahwa nilai kofisien korelasi sebesar kedua varibel yang dteliti adalah: 0,5999. Untuk menguji hipotesis atau ada tidaknya hubungan kedua variabel tersebut maka nilai hitung tersebut dikonfirmasi dengan nilai tabel Uji-R pada taraf signifikan 95\% (0,5). Adapun nilai tabel Uji-R pada pada taraf signifikan 95\% $(0,5)$ adalah: $0,4575$.

Berdasarkan hasill analisis data di atas, maka dapat dikemukakan ringkasan pengujian hipotesis sebagai berikut:

Tabel 3. Pengujian Hipotesis

\begin{tabular}{ll}
\hline Pengujian Hipotesis & \multicolumn{1}{c}{ Keterangan } \\
\hline Hipotesis alternatif & Terdapat korelasi antara tingkat keterbacaan kompetensi \\
& dasar bahasa Indonesia pada Kurikulum 2013 dan \\
& kemampuan mengajar guru guru SDN I Pakalu I \\
& Kabupaten Maros. \\
& Tidak terdapat korelasi antara tingkat keterbacaan \\
& kompetensi dasar bahasa Indonesia pada Kurikulum \\
Hipotesis nol & 2013 dan kemampuan mengajar guru guru SDN I \\
& Pakalu I Kabupaten Maros.
\end{tabular}




\begin{tabular}{ll}
\hline Pengujian Hipotesis & \multicolumn{1}{c}{ Keterangan } \\
\hline Kriteria Pengujian hipotesis & Hipotesis alternatif diterima jika nilai R hitung lebih \\
& besar daripada nila R tabel. \\
Taraf signifikansi & $95 \%(\propto 0,5)$ \\
Nilai R hitung & 0,5999 \\
Nilai R tabel & 0,4575 \\
Hasil konfirmasi nilai tabel & Nilai R hitung > R tabel \\
Penerimaan hipotesis & Hipotesis alternatif diterima, konsekweninya hipotesis \\
& nol ditolak \\
Kesimpulan & Terdapat korelasi antara tingkat keterbacaan kompetensi \\
& dasar bahasa Indonesia pada Kurikulum 2013 dan \\
& kemampuan mengajar guru SDN I Pakalu I Kabupaten \\
& Maros. \\
\hline
\end{tabular}

\section{b. Pembahasan}

Hasil analisi penelitian di atas menunjukkan bahwa secara umum tingkat keterbacaan KD bahasa Indonesia Kurikulum 2013 guru SDN I Pakalu I Kabupaten Maros. pada kategori sedang yakni dengan rata-rata skor keterbacan 69,44. Sedangkan kemampuan mengajar guru SDN I Pakalu I Kabupaten Maros juga berada pada kategori sedang dengan skor rata-rata skor 74,17. Sementara pada uji hipotesis menunjukkan bahwa nilai $\mathrm{R}$ hitung lebih besar daripada nilai $\mathrm{R}$ tabel pada taraf signifikansi $95 \%(0,5)$ yakni: $0,5999>0,45,75$. Jika dilihat dari tingkat korelasinya maka nilai kofisien korelasi 0,599 dikategorikan sangat kuat.

Hasil penelitian di atas menunjukkan bahwa kurikulum bahasa Indoensia merupakan hal yang tidak mudah dipahami. Pemahaman kurikulum tidak hanya sekadar dibaca dan dipahami, tetapi membutuhkan pencermatan mendalam terhadap substansi yang dimuat dalam kurikulum. Hal ini juga menunjukkan bahwa pembelajaran bahasa Indoensia sangat dinamis, mengalami perkembangan dari masa ke masa, sehingga subtansi yang selama ini dipahami guru mengalami perubahan sebagai suatu kebaruan.

Kondisi di atas menunjukkan bahwa dalam pengembangan Kurikulum 2013 membutuhkan kompetensi memadai oleh para guru. Oleh karena itu, penguatan dan pendalaman materi yang memadai sangat dibutuhkan. Jika hal ini tidak dilakukan maka materi tidak akan tersampaikan dengan baik, olehnya guru dalam pembelajaran. Selain itu, hal ini menunjukkan bahwa guru SD harus belajar keras dan terus menerus.

Kedua masalah tersebut memiliki keterhubungan yang sangat erat. Guru yang memahami KD dengan baik akan mampu mengajar dengan baik pula. Demikian pula sebaliknya guru yang memiliki pemahaman yang rendah terhadap KD maka memiliki kemampuan mengajar juga yang rendah.

Berdasarkan hasil penelitian ini maka dapat dipahami bahwa pembelajaran tidak akan berjalan dengan baik jika orang yang belajar (siswa) tidak belajar dan orang yang mengajar 
(guru) tidak belajar. Artinya, pembelajaran adalah kedua belah pihak, guru-murid harus terus belajar. Guru harus memiliki pemahaman yang kuat terhadapa apa yang akan diajarkan sebelum mengajarkannya.

Hal ini relevan dengan prinsip pengembangan kurikulum dipahami sebagai peningkatan berbagai aspek dalam kehidupan. Sebagaimana tujuan pengembangan kurikulum yang substansial: 1) merekonstruksi kurikulum sebelumnya; 2) menginovasi; 3) beradaptasi dengan perubahan sosial (sisi positifnya); 4) mengeksplorasi pengetahuan yang masih tersembunyi berdasarkan tujuan pendidikan nasional yang telah dirumuskan. Dari pengembangan kurikulum harus berakar, namun harus juga berpucuk menjulang tinggi, beranting, dan berdaun rindang. Berakar berarti tetap berpegang kepada falsafah bangsa dan menjulang berarti mengikuti perubahan dan perkembangan zaman (Bahri, 2014).

Hasil penelitian ini juga mengisyaratkan pentingnya pengembangan kurikulum diikuti pengembangan sumber daya manusia. Hal ini sesuai pandangan bahwa arah dan tujuan kurikulum pendidikan akan mengalami pergeseran dan perubahan seiring dengan dinamika perubahan sosial yang disebabkan oleh berbagai faktor, baik internal maupun eksternal. Karena sifatnya yang dinamis dalam menyikapi perubahan, kurikulum mutlak harus fleksibel dan futuristik. Ketimpangan-ketimpangan dalam disain kurikulum karena kurang respon terhadap perubahan sosial boleh jadi berkonsekuensi kepada lahirnya output pendidikan yang 'gagap' dalam beradaptasi dengan kondisi sosial yang dimaksud. Termasuk di dalamnya perlu adaptasi terhadap sumber daya manusia yang akan menggunakan kurikulum tersebut. (Suparlan 2013).

Hal ini juga sesuai dengan konsep sistem dalam kurikulum bahwa tidak ada subsistem dalam kurikulum yang dianggap paling penting. Semua komponen atau subsistem sama pengtingnya, sehingga harus menjadi perhatian secara terpadu dan komprehensif, termasuk peningkatan kapasitas guru dan tenaga kependidikan lainnya (Ahmad. 2011). Padangan yang mengatakan bahwa tidak ada artinya perubahan kurikulum jika tidak dibarengi dengan perubahan sumber daya manusia (Kemdikbud, 2013).

\section{Kesimpulan}

Berdasarkan hasil penelitian ini dapat disimpulkan bahwa terdapat korelasi antara tingkat keterbacaan kompetensi dasar bahasa Indonesia pada Kurikulum 2013 dan Kemampuan mengajar guru guru SDN I Pakalu I Kabupaten Maros. Hal ini dtunjukkan pada hasil uji hipotesis yakni nilai $\mathrm{R}$ hitung lebih besar daripada nilai $\mathrm{R}$ tabel pada taraf signifikansi $95 \%(0,5)$ yakni: $0,5999>0,45,75$ dengan tingkat korelasi sangat kuat. 


\section{DAFTAR PUSTAKA}

Affuni, A., Puspita, L., \& Maharani, S. D. (2021). ANALISIS TINGKAT KETERBACAAN WACANA PADA BUKU TEMATIK KURIKULUM 2013 KELAS III SEKOLAH DASAR BERDASARKAN FORMULA GRAFIK FRY (Doctoral dissertation, Sriwijaya University).

Aman, S. (2016). Analisis Keterbacaan Kompetensi Dasar Bahasa Indonesia Kurikulum 2013 Guru SD Negeri 37 Majang Kabupaten Bone. Tesis Unismuh Mahassar.

Arham, D. (2014). Membaca dan Keterbacaan Bacaan.Jakarta: Gema Media

Azis, R. (2016). Kerangka dasar dalam pengembangan kurikulum 2013. Jurnal Inspiratif Pendidikan, 5(2), 286-292.

Bahri, A. (2014). Pengembangan Kurikulum. Jakarta: Bumi Aksara.

Basyir, A. (2017). Analisis Bahan Ajar Bahasa Indonesia Kurikulum 2013. Guru-guru SD di Gugus II Kecamamatan Polewali. Jurnal. Tut Wuri Handayani. Vo. II.

Ginting, F. J. (2011). Kurikulum dalam Pandangan Beuchamp. http://jasafadilahginting.blogspot.co.id.

Febriyanti, A. L., Harsiati, T., \& Dermawan, T. (2017). Pengembangan instrumen asesmen menulis kreatif cerita fantasi untuk siswa kelas VII SMP. Jurnal Pendidikan: Teori, Penelitian, dan Pengembangan, 2(10), 1399-1408.

Hasan, I. (2000). Kurikulum dan Pembelajaran. Jakarta: Raja Grafindo Persada.

Ikhsan, K. N., \& Hadi, S. (2018). Implementasi dan pengembangan kurikulum 2013. Jurnal Edukasi (Ekonomi, Pendidikan dan Akuntansi), 6(1), 193-202.

Jayora, H. (2013). Kurikulum KBK, KTSP, dan Kurikulum 2013. http://jayharianto83.blogspot.co.id/

Kemdikbud. (2013). Kurikulum 2013. Kompetensi Inti dan Kompetensi Dasar. Jakarta: Badan Penelitian dan Pengembangan.

Kunandar. (2013). Penilaian Autentik (Penilaian Hasil Belajar Peserta Didik berdasarkan Kurikulum 2013). Jakarta: Raja Grafindo Persada.

Linda, A. (2014). Kurikulum dan Penegembangnya. Bandung: Mujahid Press.

Lisnawati, Y. (2017). Tingkat Keterbacaan Wacana Nonfiksi Pada Buku Teks Bahasa Indonesia Pegangan Siswa Kelas VII SMP Negeri 5 Raha Kurikulum 2013 Edisi Revisi 2014 dengan Menggunakan Teknik Isian Rumpang. Jurnal Bastra (Bahasa dan Sastra), 1(4).

Nisja, I. (2018). Kesesuaian Buku Teks Bahasa dan Sastra Indonesia Kelas X dengan Kurikulum 2013. Jurnal Gramatika: Jurnal Penelitian Pendidikan Bahasa dan Sastra Indonesia, 4(1), 162-172. 
Pebriana, P. H. (2021). Analisis Keterbacaan Buku Teks Siswa Kelas IV Pada Tema I Dengan Menggunakan Grafik Fry. Jurnal Pendidikan dan Konseling (JPDK), 3(1), 28-35.

Rachmad, R. (2001). Kurikulum dan Pengembangannya. Jakarta: Gema Media

Sufanti, M. (2013). Pembelajaran bahasa indonesia berbasis teks: belajar dari ohio amerika serikat. In Makalah disajikan dalam Seminar Nasional: Teks Sebagai Media Pembelajaran Bahasa Indonesia dalam menyonsong Kurikulum.

Suparlan. (2013). Tanya Jawab Pengembangan Kurikulum \& Materi Pembelajaran.Jakarta: Bumi Aksara.

Syukron. (2012). Model Pengembangan Kurikulum Hilda Taba. http://blogsyukron.blogspot.co.id. Diakses 01 Febuari 2021.

Undang -Undang Nomor 20 Tahun 2003 tentang Sistem Pendidikan Nasional

Yasinta, I. N. (2020). TINGKAT KETERBACAAN BUKU TEKS BAHASA INDONESIA KURIKULUM 2013 SISWA KELAS VIII SMPN 24 TOMPOBULU KABUPATEN MAROS (ANALISIS FAKTOR GENDER (Doctoral dissertation, Universitas Negeri Makassar).

Zahro, N. H. (2015). Analisis Tingkat Keterbacaan dalam Buku Teks Pembelajaran Tematik terpadu Kurikulum 2013 Tingkat SD/MI Kelas 2. NOSI, 3(2), 176-185. 